\title{
Genetic and Biochemical Characterization of Some Egyptian Rhizobia Isolates Nodulating Faba Bean
}

Abdel Fattah M Elzanaty, Omar A Hewedy*, Khalid S Abdel-lateif, Hisham H Nagaty and Mohamed I Abd Elbary

Genetics Department, Faculty of Agriculture, Minoufiya University, Shibin El-Kom, Egypt

\begin{abstract}
Ten Rhizobial isolates were isolated from root nodules of Faba bean plants (Viciae faba L.) grown in different soil types and representing different geographic locations in Egypt. The isolates were characterized biochemically for their production of eachIAA and catalase. The tested isolates differed in their IAA production. The maximum production of IAA production was recorded for RLZ isolate of Zefta with value of $4.56 \mu \mathrm{g} / \mathrm{ml}$, while the lowest production was recorded for RLK isolate of Kaha with $2.04 \mu \mathrm{g} / \mathrm{ml}$. Moreover, all isolates were positive in their production of Catalase enzyme except RLZ isolate. The isolates were evaluated for their plasmid content and profiles produced after cutting by two restriction endonucleases (EcoRI and MSPI). SDS-PAGE analysis was used to distinguish between the different isolates based on their banding protein patterns.
\end{abstract}

Keywords: Rhizobia; Faba bean; Catalase; IAA; Plasmid profiles; SDS-PAGE analysis

\section{Introduction}

Rhizobia are diverse group of gram-negative unicellular soil bacteria which have been widely used in agricultural systems for enhancing the ability of legumes to fix atmospheric nitrogen [1]. Nitrogen is well known to be an essential nutrient for plant growth and development $[2,3]$. Rhizobiumis able to form a nitrogen-fixing root nodules as result of symbiosis with legumes and this permit plant growth in the absence of exogenous $\mathrm{N}_{2}$ fertilizers [4,5]. In general, the symbiosis between Rhizobium and legumes species is very important and accounts for $50 \%$ of 175 million tons of total biological nitrogen fixation used in agriculture [6]. The Rhizobium leguminosarumsym biovar. Viciae (Rlv) is among fast-growing rhizobia and able to nodulate Vicia faba and Pisum sativum [7]. Faba bean (Vicia faba L.) is a major leguminous crop grown around the world and is most intensively cultivated in the North East Africa [8]. In Egypt, Faba bean is considered as one of the most important food legumes and plays a major role in the Egyptian diets as a source of protein $[9,10]$. Although the great importance of Rlv and its host Faba bean in Egypt, few molecular studies concentrated on the biodiversity of Rlv [11]. The previous studies done in other countries around the world showed the diversity and the wide distribution of $R l v$ strains [12] characterized 625 isolates of $R l v$, and concluded that Faba bean-nodulating strain formed a distinct phylogenetic subgroup of Rlv nodulation genotypes. In addition, [13] found a great genetic diversity among 75 Rhizobial isolates associated with Faba bean from China and most of these isolates were $R l v$. Moreover, [14] characterized 27 isolates collected from Italy and the RFLP analysis indicated that the majority of strains were consistent with $R l v$.

Plasmids are important genetic elements for their roles in divergence and adaptation of microbial populations against different stresses. Since, symbiosis-related genes of $R l v$ exist on plasmids [15], a study of plasmid profiling is a common means of strain identification of $R l v$ [16]. In general, $R l v$ contains from 1 to 10 plasmids which vary in size $[17,18]$. Most of the genes required for nodule formation (nod) and nitrogen fixation (nif and fix) are carried on a plasmid called the symbiotic plasmid or pSym [19-21]. Although, strains can lose some of their traits due to loss or partial deletion of a plasmid, Plasmid profiles can be considered as a stable character in rhizobia $[22,23]$. The SDS-PAGE analysis of whole cell proteins helps in identifying of the rhizobial strains $[24,25]$ and is very useful in the differentiation among the isolates within the same group [26,27]. The objectives of this study were to evaluate the diversity between ten isolates of $R l v$ from nodules of Faba bean plants representing different geographic locations in Egypt based on molecular and biochemical levels.

\section{Materials and Methods}

\section{Collection and isolation of Rhizobium isolates}

Ten isolates of $R l v$ were isolated from nodules of Faba bean plants (Vicia faba L.) representing different soil types and geographic locations in Egypt (Table 1) according to the methods [28]. The samples collection area were planned to cover approximately the cultivated governorates in Egypt and with soil types varied from sand, loam to clay (Table 1).

\begin{tabular}{|c|c|c|}
\hline Isolate code & Soil type & Location \\
\hline RLQ & Clay & Quesna City \\
\hline RLS & Sand & Sadat City \\
\hline RLZ & Clay & Zefta City \\
\hline RLB & Clay & Benisuef City \\
\hline RLT & loam & El-tor City \\
\hline RLA & loam & El-Arish City \\
\hline RLM & loam & El-Menia City \\
\hline RLK & Clay & Kaha City \\
\hline RLG & Clay & El- Giza City \\
\hline RLI & Sand & El-lsmailia City \\
\hline
\end{tabular}

Table 1: Name of isolates and its locations.

*Corresponding author: Omar A Hewedy, Department of Genetics, Menoufia University, Shibin El-Kom, Egypt, Tel: +02 - 01223570768; E-mail: hewedy.omar@gmail.com

Received January 13, 2015; Accepted March 10, 2015; Published March 17 2015

Citation: Elzanaty AFM, Hewedy OA, Abdel-lateif KS, Nagaty $\mathrm{HH}$, Abd Elbary MI (2015) Genetic and Biochemical Characterization of Some Egyptian Rhizobia Isolates Nodulating Faba Bean. J Microb Biochem Technol 7: 083-087. doi:10.4172/1948-5948.1000186

Copyright: (c) 2015 Elzanaty AFM, et al. This is an open-access article distributed under the terms of the Creative Commons Attribution License, which permits unrestricted use, distribution, and reproduction in any medium, provided the original author and source are credited 
Citation: Elzanaty AFM, Hewedy OA, Abdel-lateif KS, Nagaty HH, Abd Elbary MI (2015) Genetic and Biochemical Characterization of Some Egyptian Rhizobia Isolates Nodulating Faba Bean. J Microb Biochem Technol 7: 083-087. doi:10.4172/1948-5948.1000186

\section{Biochemical characterization of $r l v$ isolates}

IAA production test: All the isolates were tested for IAA production in Yeast Extract Mannitol (YEM) broth [28] supplemented with $100 \mu \mathrm{g} / \mathrm{ml} \mathrm{L-tryptophan.} \mathrm{The} \mathrm{test} \mathrm{tubes} \mathrm{were} \mathrm{covered} \mathrm{with} \mathrm{brown}$ paper and incubated at $28^{\circ} \mathrm{C}$ for 5 days on a rotary shaker. The broth was centrifuged at $10,000 \mathrm{rpm}$ for 15 minutes. $2 \mathrm{ml}$ of supernatant was collected and 2-3 drops of o-phosphoric acid were added. The aliquots were shaken, added $4 \mathrm{ml}$ of reagent $\left(1 \mathrm{ml}\right.$ of $0.5 \mathrm{M} \mathrm{FeCl}_{3}$ in $49 \mathrm{ml}$ of $35 \%$ perchloric acid ( $\mathrm{HClO} 4)$ and vortexed thoroughly. The samples were incubated at room temperature for 25 minutes and their absorbance was read at $530 \mathrm{~nm}$. Auxin quantification value was recorded by extrapolating calibration curve made by using IAA as standard (10-100 $\mu \mathrm{g} / \mathrm{ml})[29,30]$.

Catalase test: Catalase activity of $R l v$ isolates was tested according to [31] with modifications. Two drops of hydrogen peroxide $\left(\mathrm{H}_{2} \mathrm{O}_{2}\right)$ were added to $72 \mathrm{~h}$ old isolates growing on YEM plates and checked for formation of oxygen gas bubbles.

\section{Plasmid isolation and digestion}

Plasmid DNA was isolated by the method of [32]. The extracted plasmids were digested with EcoRI and MSPI enzymes according to Thermo scientific fermentas kit (http://www.thermoscientificbio.com/ fermentas/)

\section{Protein banding patterns of rhizobial isolates}

The cultures of Rlv isolates growing on Broth YEM medium were pelleted and resuspended in $40 \mu \mathrm{l}$ of Laemmli Sample Buffer, $5 \mu \mathrm{l}$ of $10 \%$ SDS and $5 \mu \mathrm{l}$ of $\beta$-mercaptoethanol. The mixture was then boiling for $5 \mathrm{~min}$ and centrifugation to obtain the supernatant which contains proteinfractionations. Sodium dodecyl sulfate- polyacrylamide gel electrophoresis (SDS-PAGE) was performed [33].

\section{Statistical Analysis}

Data obtained were statistically analyzed using SPSS analysis program (version 11.5) using SPSS Statistical Package with Duncan's multiple-range test at 5\% level of Significance. The NTSYS-pc version $2.11 \mathrm{~W}$ (Numerical Taxonomy System) program was used to perform cluster analysis based on Jaccard's similarity coefficient. Dendrogram was constructed according to the Unweighted Pair-Group Method with Arithmetical average (UPGMA) clustering method.

\section{Results and Discussion}

\section{Biochemical characterization of $r l v$ isolates}

A. Catalase activity: Active oxygen such as $\mathrm{H}_{2} \mathrm{O}_{2}$ is well known to damage the proteins, lipids and DNA components. The previous studies have shown that catalase plays an important role in the defense of cells against these toxic forms of oxygen and increasing of catalase activity in rhizobia could be useful to improve the nitrogen-fixing efficiency of nodules by the reduction of $\mathrm{H}_{2} \mathrm{O}_{2}$ content [34]. Hence, all of tested isolates were evaluated for their catalase activity by adding two drops of $\mathrm{H}_{2} \mathrm{O}_{2}$ to isolates growing on YEM plates and checked for formation of oxygen gas bubbles as indicator of catalase activity. Results in Table 2 and Figure 1 showed that all of $R l v$ isolates were positive in their production of Catalase enzyme except RLZ isolate. It is not understood why RLZ isolate was negative in catalase production. One of explanations is that there are different kinds of catalase and may be one kind was impaired.

B. IAA production test: Since Indole-3-acetic acid (IAA) plays

\begin{tabular}{|l|l|l|l|l|l|l|l|l|l|}
\hline \multicolumn{1}{l|}{ Rhizobial isolates } \\
\hline RLQ & RLS & RLZ & RLB & RLT & RLA & RLM & RLK & RLG & RLI \\
\hline+ & + & --- & + & + & + & + & + & + & + \\
\hline
\end{tabular}

Where as, $(+)$ means positive and (-) means negative for catalase activity. Table 2: Catalase activity in $R / v$ isolates.

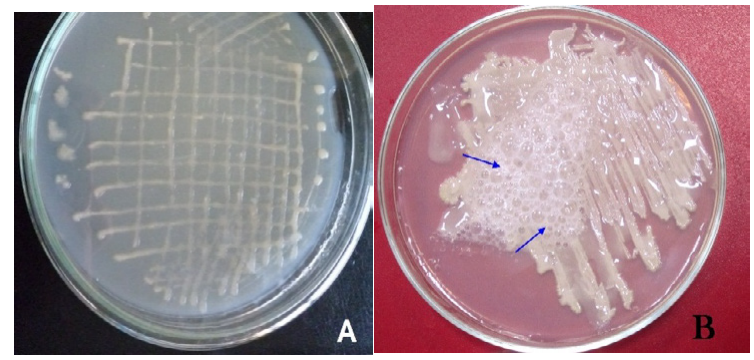

Figure 1: Testing of catalase activity by detection of oxygen gas bubbles.

A: Before $\mathrm{H}_{2} \mathrm{O}_{2}$ addition

B: After $\mathrm{H}_{2} \mathrm{O}_{2}$ addition

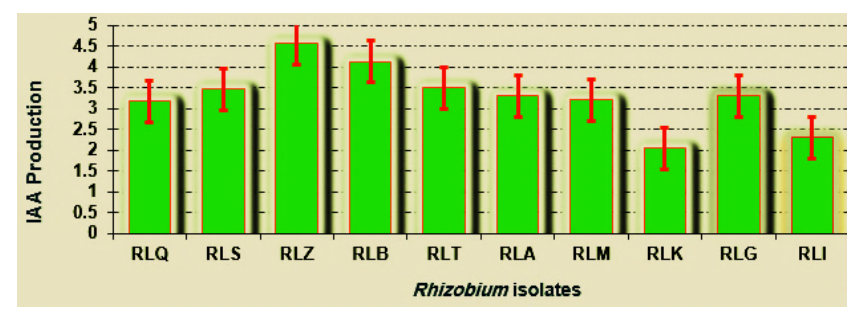

Figure 2: Production of IAA $(\mu \mathrm{g} / \mathrm{ml})$ by $R / v$ isolates.

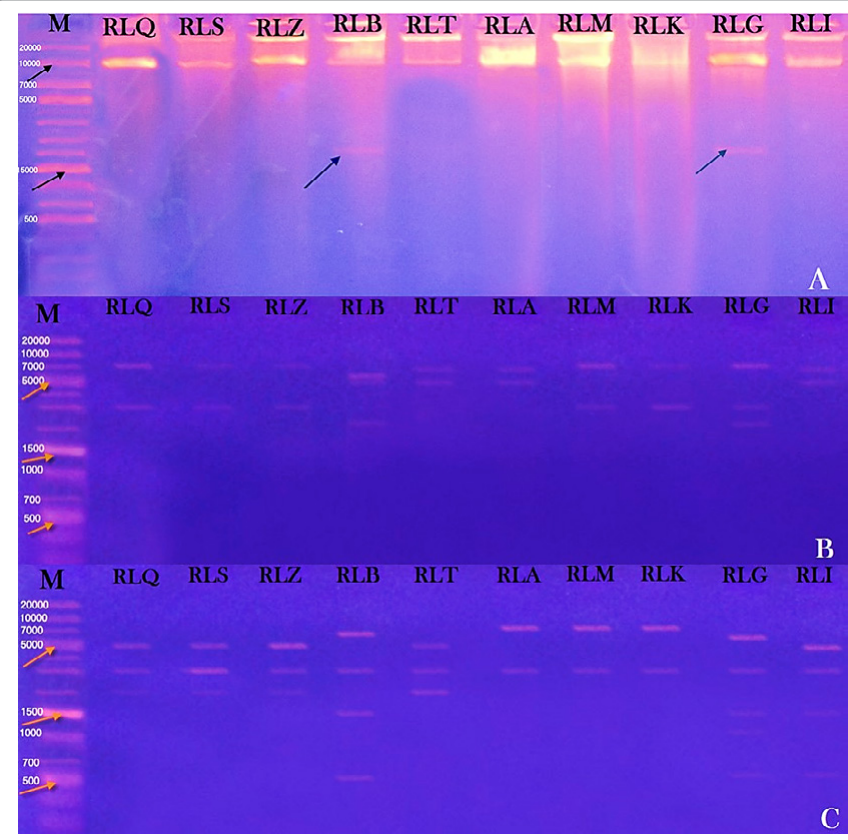

A: The plasmid content of $R / v$ isolates; $\mathrm{B}$ :Digestion of plasmid with $\mathrm{ECORI}$; C: Digestion of plasmid by MSPI.

Figure 3: Plasmids profile of $R / v$ isolates.

a significant role in regulating cellular elongation, differentiation, cellulardivision, apoptosis, and nodule formation in plants $[35,36]$. Rhizobia are known to produce significant levels of IAA both in free 
living conditions and also symbiotically in nodules [37]. Hence, the $R l v$ isolates were screened for their ability to produce plant growth regulator, IAA. All isolates showed different colors after treatment with Salkowaski reagent indicating variation in their abilities to produce IAA. The range of IAA productionvaried from 2.04 (RLK of Kaha) to $4.56 \mu \mathrm{g} / \mathrm{ml}$ (RLZ of Zefta). These results are in accord withprevious studies haveshowing that Production of IAA by microbial isolates varies greatly among different species and strains and depends on the availability of substrate(s) (Figure 2)[38].

\section{Molecular characterization of RLV isolates}

A. Plasmid profiles: RLV isolates were analyzed for their plasmid content and profiles. In general, all the isolates harbored one plasmid with size of $10 \mathrm{~kb}$, while two isolates (RLB of Benisuef and RLG of Giza) contained an additional plasmid with size of $2 \mathrm{~kb}$
(Figure 3A). These results are in agreement with previous studies have shown that most of the Rhizobial species harbour plasmids that vary in number (1 to 10$)$ and in size $[39,40]$. Two restriction endonucleases, MspI and ECORI were used to digest the plasmids and studying their restriction profiles. The isolates of RLQ, RLA, RLZ, RLM and RLK have the same profile after digestion by ECORI and shared two bands of 7 and $3 \mathrm{~kb}$ (Figure 3). On the other hand, the isolates RLB and RLG gave three different bands. It must be mentioned that digestion with MspI showed more bands than ECORI. Moreover, the isolates RLA, RLM and RLK have the same profile as indicated with ECORI, while isolates RLQ, RLS and RLZ shared same profile and produced three bands of 5, 3 and $2 \mathrm{~kb}$ (Figure 3C). In addition, the isolates RLB, RLI and RLG produced the highest number of bands with 4, 4 and 5 bands respectively. These results show variation between isolates based on plasmid restriction profiles and are homologous with these obtained

\begin{tabular}{|l|l|l|l|l|l|l|l|l|l|l|}
\hline & RLQ & RLS & RLZ & RLB & RLT & RLA & RLM & \\
\hline RLQ & 1.00 & & & & & \\
\hline RLS & 0.54 & 1.00 & & & & & \\
\hline RLZ & 0.54 & 0.81 & 1.00 & & & & \\
\hline RLB & 0.63 & 0.90 & 0.72 & 1.00 & & & \\
\hline RLT & 0.54 & 1.00 & 0.81 & 0.90 & 1.00 & & \\
\hline RLA & 1.00 & 0.54 & 0.54 & 0.63 & 0.54 & 1.00 & & \\
\hline RLM & 1.00 & 0.54 & 0.54 & 0.63 & 0.54 & 1.00 & \\
\hline RLK & 1.00 & 0.54 & 0.54 & 0.63 & 0.54 & 1.00 & \\
\hline RLG & 0.90 & 0.63 & 0.63 & 0.72 & 0.63 & 0.90 & \\
\hline RLI & 1.00 & 0.54 & 0.54 & 0.63 & 0.54 & 1.00 & \\
\hline
\end{tabular}

Table 3: Similarity matrix among RLV isolates as revealed by protein banding patterns based on Jacard's coefficient.

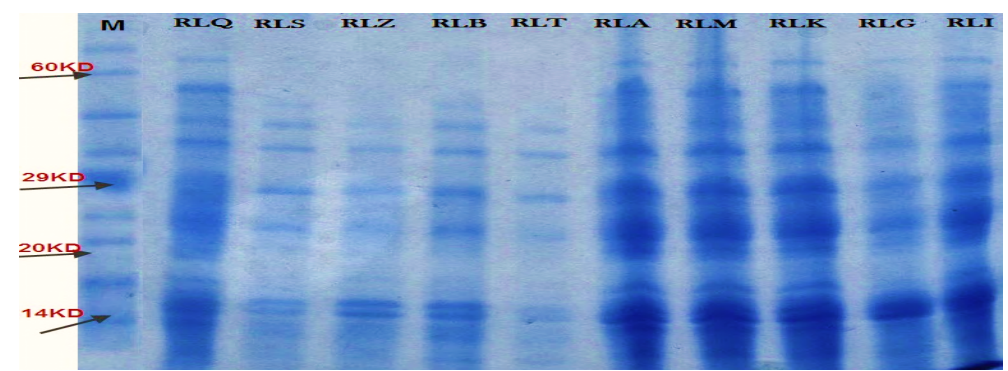

Figure 4: SDS-PAGE protein banding patterns of RLV isolates grown in Broth YEM medium. M: Molecular weight standard (PageRulerTM protein ladder, Fermentas).

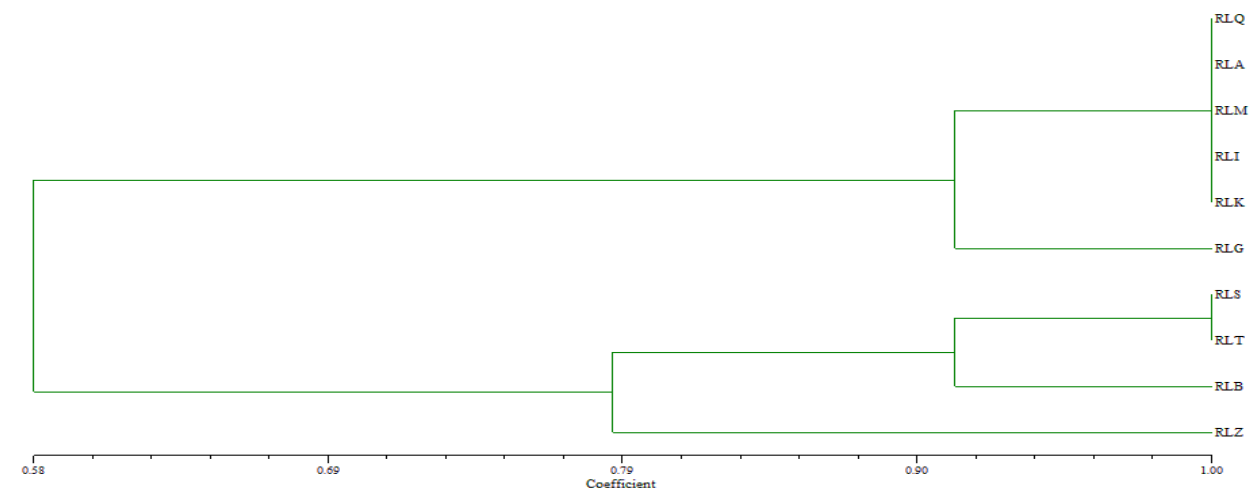

Figure 5: The relationship between $R L V$ isolates based on Jacard's coefficient as revealed by protein banding patterns. 
Citation: Elzanaty AFM, Hewedy OA, Abdel-lateif KS, Nagaty HH, Abd Elbary MI (2015) Genetic and Biochemical Characterization of Some Egyptian Rhizobia Isolates Nodulating Faba Bean. J Microb Biochem Technol 7: 083-087. doi:10.4172/1948-5948.1000186

by [16] who used different restriction endonucleases to digest the amplified DNA.

B. Protein banding patterns analysis: The protein banding patterns of the Rlv isolates were detected using SDS-PAGE analysis and were used to classify these isolates as shown in Figure 4 . The size of detected bands ranged from 14 to $70 \mathrm{KD}$. The similarity matrix among the isolates was recorded based on Jacard's coefficient as revealed by protein banding profiles (Table 3 ). The highest values of similarity were between isolates RLS and RLT; RLA and RLQ; RLM and RLQ; RLA and RLM; RLA and RLK; RLM and RLK; also between RLI and RLM, RLA and RLK isolates with $100 \%$ similarity (Table 3 ). While, the lowest values of similarity were recorded between the RLQ and RLS, RLZ and RLT; RLS and RLA; RLS and RLM; RLA and RLZ; RLZ and RLM; RLS and RLK; RLK and RLM with 54\% similarity. The similarity values divided the ten isolates into two main clusters (Figure 5), the first cluster contained the isolates (RLA, RLQ, RLG, RL M, RLK and RLI) while the second contained the isolates (RLB, RLS, RLT and RLZ). In general, the values of similarity among isolates based protein profiles are high, it is possible that these isolates has originated from the same genotypes and the human activities like soil and plant transfer limited the genetic diversity between these isolates. These results are in agreement with previous studies showing that different isolates of Rhizobia may have the same origin [41-43]. Moreover, it was indicated that rhizobia population in China probably originated from those of Japan and North America [44].

\section{References}

1. Teaumroong N, Boonkerd N (1998). Detection of Bradyrhizobium spp. and B japonicum in Thailand by primer-based technology and Direct DNA Extraction. Plants and Soil 204: 127-134.

2. Glick BR (2012) Plant growth-promoting bacteria: mechanisms and applications, Scientifica 2012.

3. Batut J, Mergaert P, Masson-Boivin C (2011) Peptide signalling in the rhizobium-legume symbiosis. Curr Opin Microbiol 14: 181-187.

4. Allen ON and Allen EK (1981)The Leguminosae - a Book of Characteristics, Uses and Nodulation. Macmillan, London.

5. Zakhia F, de Lajudie P (2001)Taxonomy of rhizobia. Agronomie 21: 569-576.

6. Hatice O, Ömer F, Erdal E, Faik K (2008) The Determination of Symbiotic Effectiveness of Rhizobium Strains Isolated from Wild Chickpeas Collected from High Altitudes in Erzurum. Turk J Agric Forest Sci 32: 241-248.

7. Doyle, J.J (1998) Phylogenetic perspectives on nodulation: evolving views of plants and symbiotic bacteria. Trends in Plant Science 3: 473-478.

8. Bond DA (1976) Field bean (Vicia faba). In: Simmonds NW (ed.) Evolution of Crop Plants. Longman and Hall, London, pp. 179-182.

9. El-Bramawy MA, El-Besheh EKF (2011) The Resistance of Bean Yellow Mosaic Virus (BYMV) inFaba bean (Vicia faba L.) with Diallel Analysis. Journal of Biology and Life Science 2.

10. Hassan AA (1996) Eldar Production of vegetable crops. ELarabia Lil NashrWaEltawzia 710

11. Shamseldin AM, El-Saadani, Sadowsky MJ, An CS (2009) Rapid identification and discrimination among Egyptian genotypes of Rhizobium leguminosarum bv. viciae and Sinorhizobium meliloti nodulating Faba bean (Vicia faba L.) by analysis of nodC, ARDRA, and rDNA sequence analysis. Soil Biol Biochem 41: 45-53.

12. Mutch LA, Young JP (2004) Diversity and specificity of Rhizobium leguminosarum biovar viciae on wild and cultivated legumes. Mol Ecol 13: 2435-2444.

13. Tian CF, Wang ET, Han TX, Sui XH, Chen WX (2007) Genetic diversity of rhizobia associated with Vicia faba in three ecological regions of China. Arch Microbiol 188: 273-282.
14. Moschetti G, Peluso A, Protopapa A, Anastasio M, Pepe O, et al. (2005) Use of nodulation pattern, stress tolerance, nodC gene amplification, RAPDPCR and RFLP-16S rDNA analysis to discriminate genotypes of Rhizobium leguminosarum biovar viciae. Syst Appl Microbiol 28: 619-631.

15. Mazurier SI, Laguerre G (1997) Unusual location of nod and nifgenes in Rhizobium leguminosarumbv. viciae. Can J Microbiol 43: 399-402.

16. Vessey JK, George NC (2006) The genetic diversity of Rhizobium leguminosarum bv. viciae in cultivated soils of the eastern Canadian prairie. Soil Biol Biochem 38: 153-163.

17. Romero ME, Mellado JC (1996) Rhizobium phylogenies and bacterial genetic diversity. Crit Rev Plant Sci 15: 113-140.

18. Blanco MJ, Toro N (1996) Plasmids in Rhizobia: the role of nonsymbiotic plasmids. Mol Plant-Microbe Interact 9: 535-545.

19. García-de Los Santos A, Brom S, Romero D (1996) Rhizobium plasmids in bacteria-legume interactions. World J Microbiol Biotechnol 12: 119-125.

20. Romero ME, Palacios R (1990) The Rhizobium genome. Crit Rev Plant Sci 9 59-93.

21. Mazur A, Majewska B, Stasiak G, Wielbo J, Skorupska A (2011) repABC-based replication systems of Rhizobium leguminosarum bv. trifolii TA1 plasmids: incompatibility and evolutionary analyses. Plasmid 66: 53-66.

22. Djordjevic MA, Zurkowski W, Rolfe BG (1982) Plasmids and stability of symbiotic properties of Rhizobium trifolii. J Bacteriol 151: 560-568.

23. Weaver RW, Wei GR, Berryhill DL (1990). Stability of plasmids in R. phaseoli during culture. Soil Biol Biochem 22: 465-469.

24. Roberts GP, Leps WT, Silver LE, Brill WJ (1980) Use of two-dimensional polyacrylamide gel electrophoresis to identify and classify Rhizobium strains. Appl Environ Microbiol 39: 414-422.

25. Fabiano E, Arias A (1990) Identification of inoculant strains and naturalized populations ofRhizobium leguminosarum bvtrifolii using complementary methodologies. World J Microbiol Biotechnol 6: 121-126.

26. Shoukry AA, Khattab AA, Abou-Ellail M, El-shabrawy H (2013) Molecular and biochemical characterization of new Rhizobium leguminosarum bv. viciae strains isolated from different located of Egypt. J Appl Sci Res 9: 5864-5877.

27. Amer MM (2008b) Monitoring of variation among Faba bean Rhizobium isolates: 2. Biodegradation of herbicide 3 (3, 4-dichlorophenyl)-1-methoxy-1methyl urea. J Appl Sci Res 2: 540-548.

28. Vincent JM (1970) A Manual for the Practical Study of Root-Nodule Bacteria Blackwell Scientific Publications, Oxford.

29. Gordon SA, Weber RP (1951) COLORIMETRIC ESTIMATION OF INDOLEACETIC ACID. Plant Physiol 26: 192-195.

30. Hung PQ, Annapurna K (2004) Isolation and characterization of endophytic bacteria in soybean (Glycine Sp.). Omonrice 12: 92-101.

31. McFadden JF (1980) Biochemical tests for identification of medical bacteria (2ndedn.) Williams and Wilkins, Baltimore.

32. Birnboim HC, Doly J (1979) A Rapid Alkaline Extraction Procedure for Screening Recombinant Plasmid DNA. Nucleic Acids Res 7: 1513-1523.

33. Abdel-lateif K, Hewedy O, El-Zanaty A (2014) Molecular screening of some Egyptian Rhizobium isolates under salt stress. Inter J Sci Res 11: 11-15.

34. Orikasa Y, Nodasaka Y, Ohyama T, Okuyama H, Ichise N, et al. (2010) Enhancement of the nitrogen fixation efficiency of genetically-engineered Rhizobium with high catalase activity. J Biosci Bioeng 110: 397-402.

35. Paponov IA, Paponov M, Teale W, Menges M, Chakrabortee S, et al. (2008) Comprehensive transcriptome analysis of auxin responses in Arabidopsis. Mol Plant 1: 321-337.

36. Yamada T (1993) The role of auxin in plant-disease development. Annu Rev Phytopathol 31: 253-273.

37. Ernstsen A, Sandberg G, Crozier A, Wheeler CT (1987) Endogenous indoles and the biosynthesis and metabolism of indole-3-acetic acid in cultures of Rhizobium phaseoli. Planta 171: 422-428.

38. Shahab S, Ahmed N, Khan NS (2009) Indole acetic acid production and 
Citation: Elzanaty AFM, Hewedy OA, Abdel-lateif KS, Nagaty HH, Abd Elbary MI (2015) Genetic and Biochemical Characterization of Some Egyptian Rhizobia Isolates Nodulating Faba Bean. J Microb Biochem Technol 7: 083-087. doi:10.4172/1948-5948.1000186

enhanced plant growth promotion by indigenous PSBs. Afri J Microbiol Res 4: $1312-1316$.

39. Nahar M, Mahal Z, Zahid HM, Zaman K, Jahan F, et al (2012) Effects of plasmid curing on Rhizobium spp. J Microbiol 2.

40. Lakzian A, Murphy P, Turner A, Beynon JL, Giller KE (2002) Rhizobium leguminosarum bv. viciae populations in soils with increasing heavy meta contamination: abundance, plasmid profiles, diversity and metal tolerance. Soil Bio Biochem 34: 519-529.
41. Hewedy OA, Eissa RA, Elzanaty AM, Nagaty HH, AbdElbary MI (2014) Phenotypic and Genotypic Diversity of Rhizobia Nodulating Faba Bean from Various Egyptian Locations. J Bioproces Biotechniq 4: 170-178.

42. Ismail M, El-Zanatay AM, Eissa RA, Hewedy OA (2013) Genetic Diversity of Rhizobiumleguminosarum as Revealed by $16 \mathrm{~S}$ rRNA Gene Sequence. American-Eur J Agric Environ Sci 13: 797-801.

43. Moreira FM, Haukka K, Young JP (1998) Biodiversity of rhizobia isolated from a wide range of forest legumes in Brazil. Mol Ecol 7: 889-895.

44. Yang JK, Zhou JC (2008) Diversity, phylogeny and host specificity of soybean and peanut bradyrhizobia. Biol Fertil Soil 44: 843-851. 